\title{
An autocrine sphingosine-1-phosphate signaling loop enhances NF-kB-activation and survival
}

\author{
Tomas Blom 1,5, Nina Bergelin 1,4, Annika Meinander2,3,6, Christoffer Löf1, J Peter Slotte2, John E Eriksson 1,3 and \\ Kid Törnquist*1,4
}

\begin{abstract}
Background: Sphingosine-1-phosphate (S1P) is a bioactive lipid that regulates a multitude of cellular functions, including cell proliferation, survival, migration and angiogenesis. S1P mediates its effects either by signaling through $G$ protein-coupled receptors (GPCRs) or through an intracellular mode of action. In this study, we have investigated the mechanism behind S1P-induced survival signalling.

Results: We found that S1P protected cells from FasL-induced cell death in an NF-KB dependent manner. NF-KB was activated by extracellular S1P via S1P 2 receptors and $G_{i}$ protein signaling. Our study also demonstrates that extracellular S1P stimulates cells to rapidly produce and secrete additional S1P, which can further amplify the NF-kB activation.

Conclusions: We propose a self-amplifying loop of autocrine S1P with capacity to enhance cell survival. The mechanism provides increased understanding of the multifaceted roles of S1P in regulating cell fate during normal development and carcinogenesis.
\end{abstract}

\section{Background}

Sphingolipids regulate cellular processes such as migration, survival and differentiation [1,2]. Sphingosine-1phosphate (S1P), the most extensively studied of the bioactive sphingolipids, acts as a high affinity agonist at five known $\mathrm{G}$ protein-coupled receptors named $\mathrm{S}_{1} \mathrm{P}_{1}-\mathrm{S}_{\mathrm{P}} \mathrm{P}_{5}$ [3]. The S1P-receptors are important for regulating cell migration [4-6], proliferation and survival [7]. In addition, it has been shown that S1P can act intracellularly as a calcium releasing second messenger $[8,9]$ and as a regulator of histone acetylation and transcription [10]. It is likely that some effects attributed to intracellular S1P can also be explained by signaling through internalized G protein-coupled receptors [11,12].

S1P is synthesized through sphingosine kinase (SphK) catalyzed phosphorylation of sphingosine. Type 1 sphingosine kinase (SphK1) is generally associated with cell survival, and several mechanisms for regulating its function have been identified. Growth factors [13,14], cytokines $[15,16]$, and even S1P itself $[17,18]$ have been shown to stimulate SphK-activity and S1P-production. ERK1/2

\footnotetext{
* Correspondence: ktornqvi@abo.fi

1 Department of Biology, Åbo Akademi University, 20520 Turku, Finland Full list of author information is available at the end of the article
}

mediated phosphorylation on Ser225 directly activates SphK1, and this is also a prerequisite for the translocation of SphK1 to the plasma membrane [19]. Furthermore, binding to $\mathrm{Ca}^{2+}$-calmodulin has been shown to be crucial for translocation of SphK1 to the plasma membrane $[20,21]$. SphK1 may also be regulated by lipids such as phosphatidylserine [22] or phosphatidic acid [23].

An increase in SphK1-activity often correlates with enhanced survival and proliferation. Several studies have shown that intracellular S1P is exported and acts on G protein coupled S1P-receptors to induce survival signaling [24-26]. SphK1 itself may also be exported from cells and retain its catalytic function in the extracellular space $[27,28]$, thus synthesizing S1P that has access to S1Preceptors in the plasma membrane.

In this study, we have investigated the signaling mechanisms activated by exogenous S1P, and in particular the effects of the subsequent increase in cellular S1P-production. We found that S1P mediated protection from death receptor-induced apoptosis in an NF- $\mathrm{kB}$ dependent manner. Intriguingly, exogenously added S1P induced several cell types to synthesize and secrete additional S1P. The $\mathrm{S} 1 \mathrm{P}$ that is secreted from cells can further enhance NF- $\mathrm{kB}$ activation through $\mathrm{G}$ protein coupled S1P-receptors. We 
A
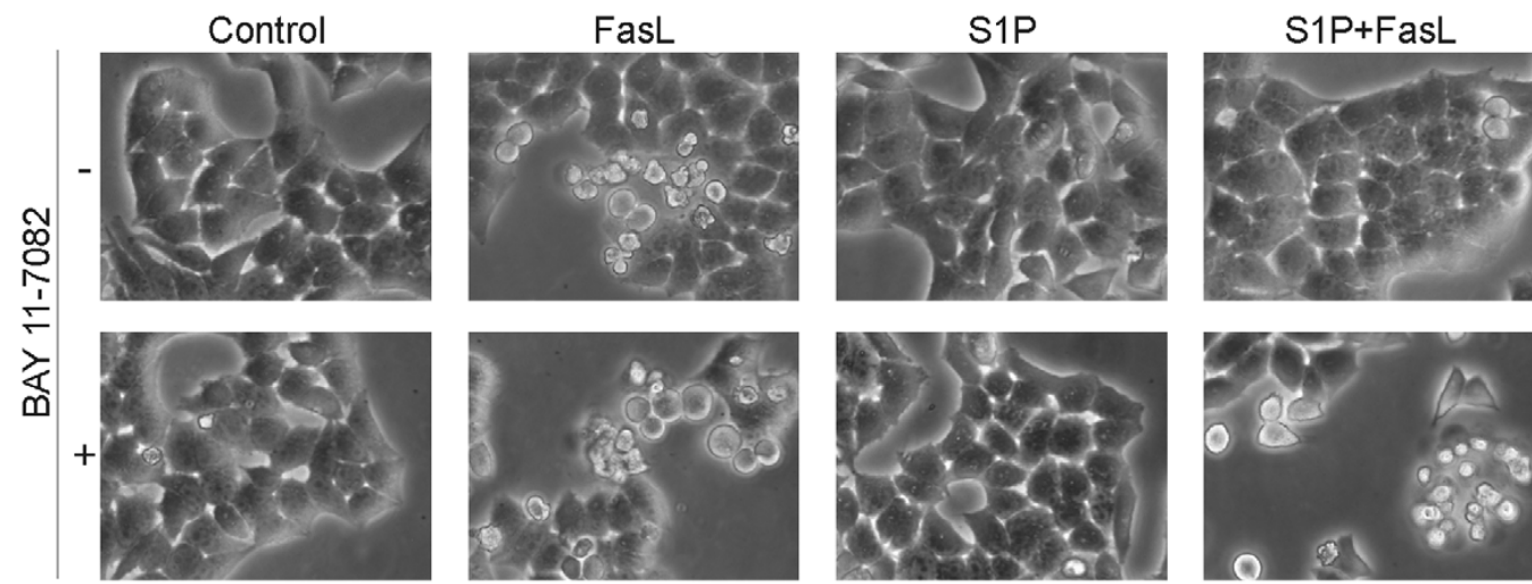

B
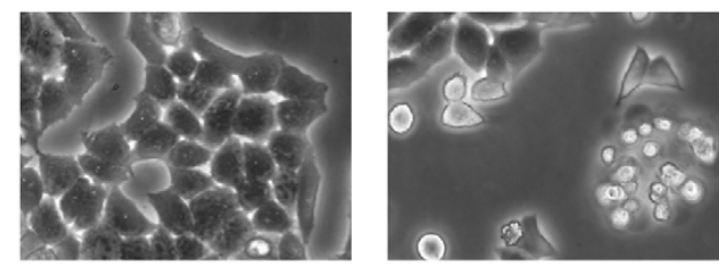

C
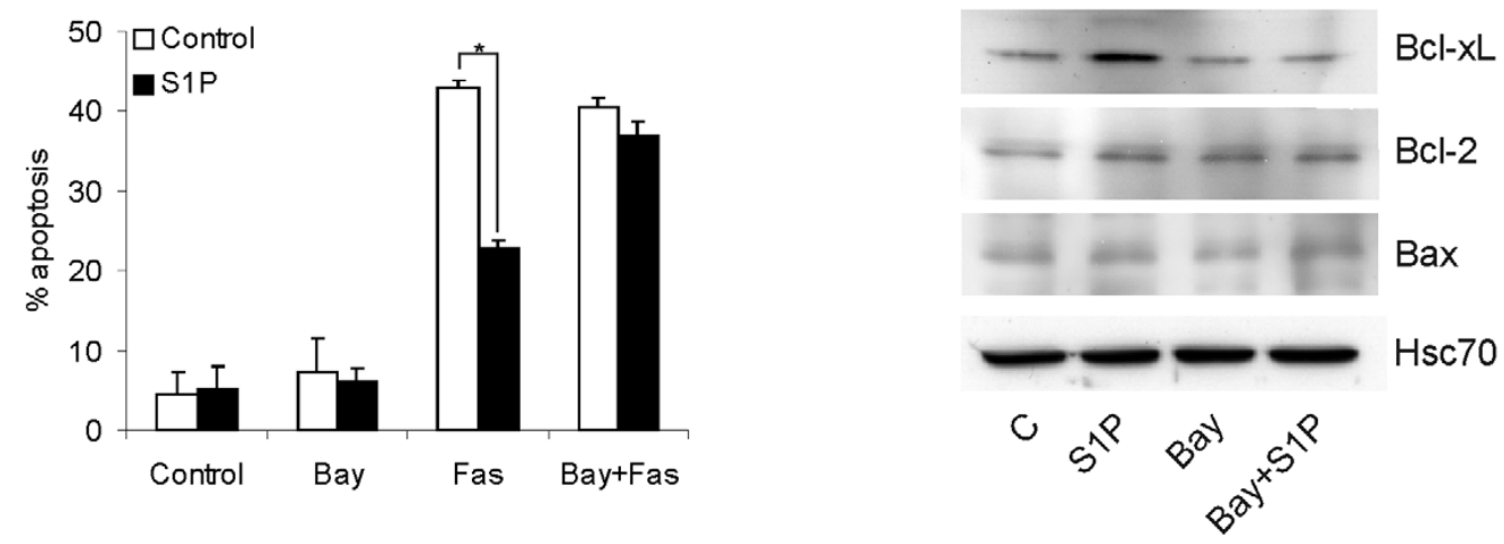

Figure $1 \mathrm{~S} 1 \mathrm{P}$ confers NF-KB dependent protection from death receptor induced apoptosis. Figure $\mathbf{A}$ shows representative phase contrast pictures of HeLa cells treated $\pm 5 \mu \mathrm{M}$ Bay 11-7082 (NF-KB inhibitor) for $6 \mathrm{~h}$, followed by addition of vehicle or $3 \mu \mathrm{M}$ S1P for 8 hours. Apoptosis was then induced by addition of $50 \mathrm{ng} / \mathrm{ml}$ superFas ligand (Fas) for 16 hours. B. HeLa cells were treated as in A, and were fixed, stained for active caspase-3, and were analysed by FACS. The bars denote the mean \pm SEM of at least three independent experiments $\left({ }^{*}, \mathrm{p}<0.05\right)$. C. Western blot showing BCl- $\mathrm{X}_{\mathrm{L}}, \mathrm{BCl}-$

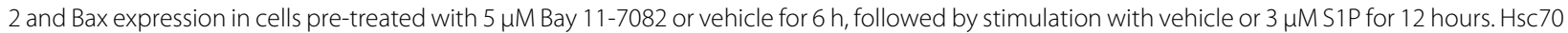
was used as a loading control. The results are representative of three independent experiments.

demonstrate here that a $\mathrm{G}$ protein coupled receptor agonist can induce its own production and secretion at physiologically relevant levels.

\section{Methods}

\section{Materials}

Fluo-3 AM and BAPTA AM were purchased from Molecular Probes (Eugene, OR, U.S.A.). D-erythro-sphingosine-1-phosphate, D-erythro-N,N-dimethylsphingosine, dihydro-sphingosine-1-phosphate, and GF109203× were from Biomol (Plymouth meeting, PA, U.S.A.) and D-erythro-sphingosine from Sigma (St. Louis, MO, U.S.A.). Phorbol 12-myristate 13-acetate (PMA), the sphingosine kinase inhibitor $2-(p-$ Hydroxyanilino)-4-( $p$ - chlorophenyl)thiazole (SKi), PD98059, Bay 11-7082, and Wortmannin were from Calbiochem (Darmstadt, Germany). $\left[{ }^{3} \mathrm{H}\right]$-sphingosine was from NEN Life Science Products (Boston, MA, U.S.A.). U73122 and Pertussis toxin were purchased from Sigma (St Louis, MO, U.S.A.). VPC 23019 was from Avanti (Alabaster AL, U.S.A.). FLAG-tagged TRAIL and SuperFasLigand were from Alexis (San Diego, CA, U.S.A.). TRAIL was crosslinked with M2 anti-FLAG antibody (Sigma, St. Louis, MO, U.S.A.) prior to stimulating cells. The $\mathrm{S}_{2,4,5}$ antibodies were from Santa Cruz Biotechnology (Santa Cruz, CA, U.S.A.), and the $\mathrm{S}_{1} \mathrm{P}_{1,3}$ antibodies were from both Santa Cruz and Cayman Chemicals (Ann Arbor, MI, U.S.A.). 

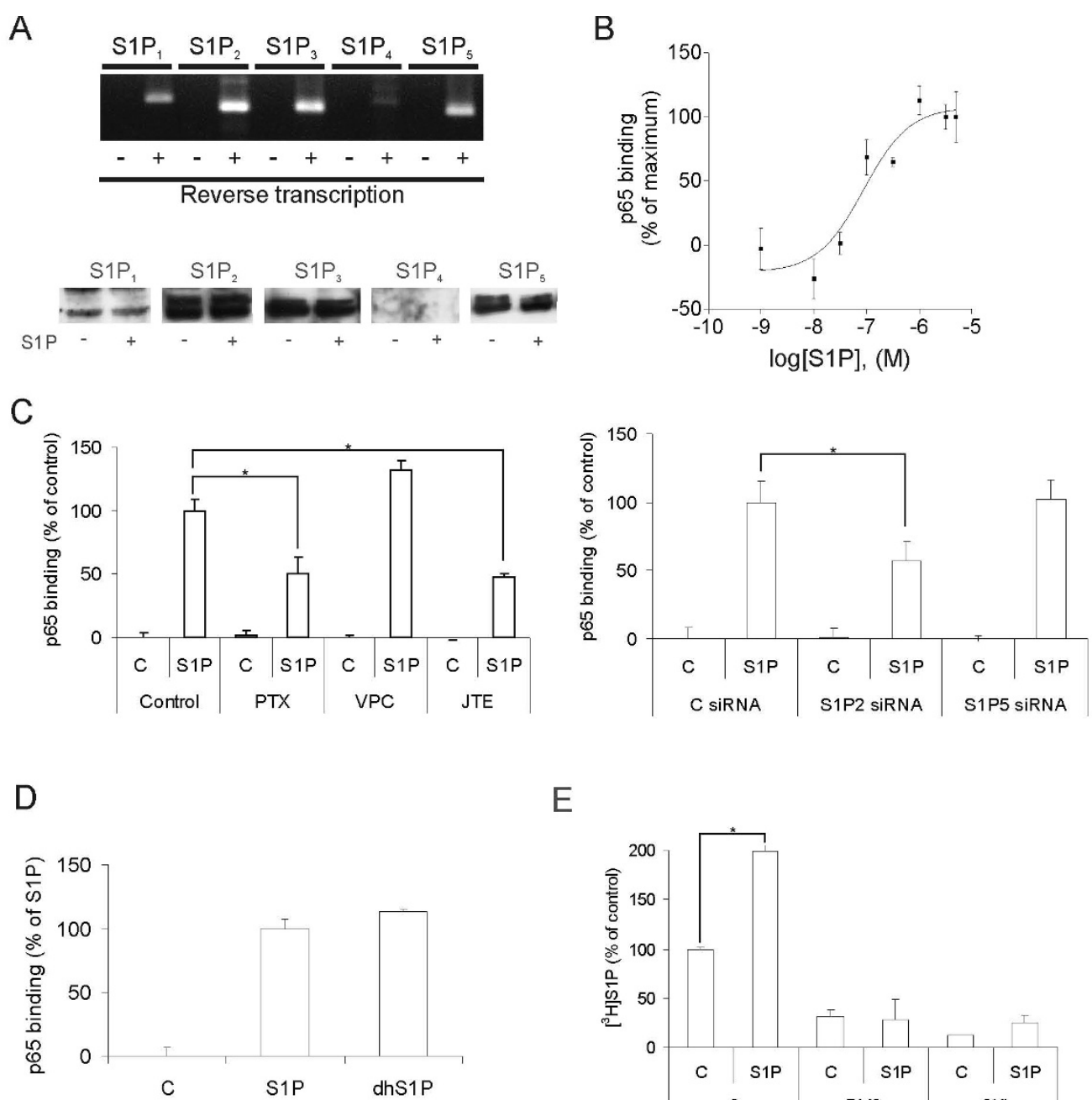

E
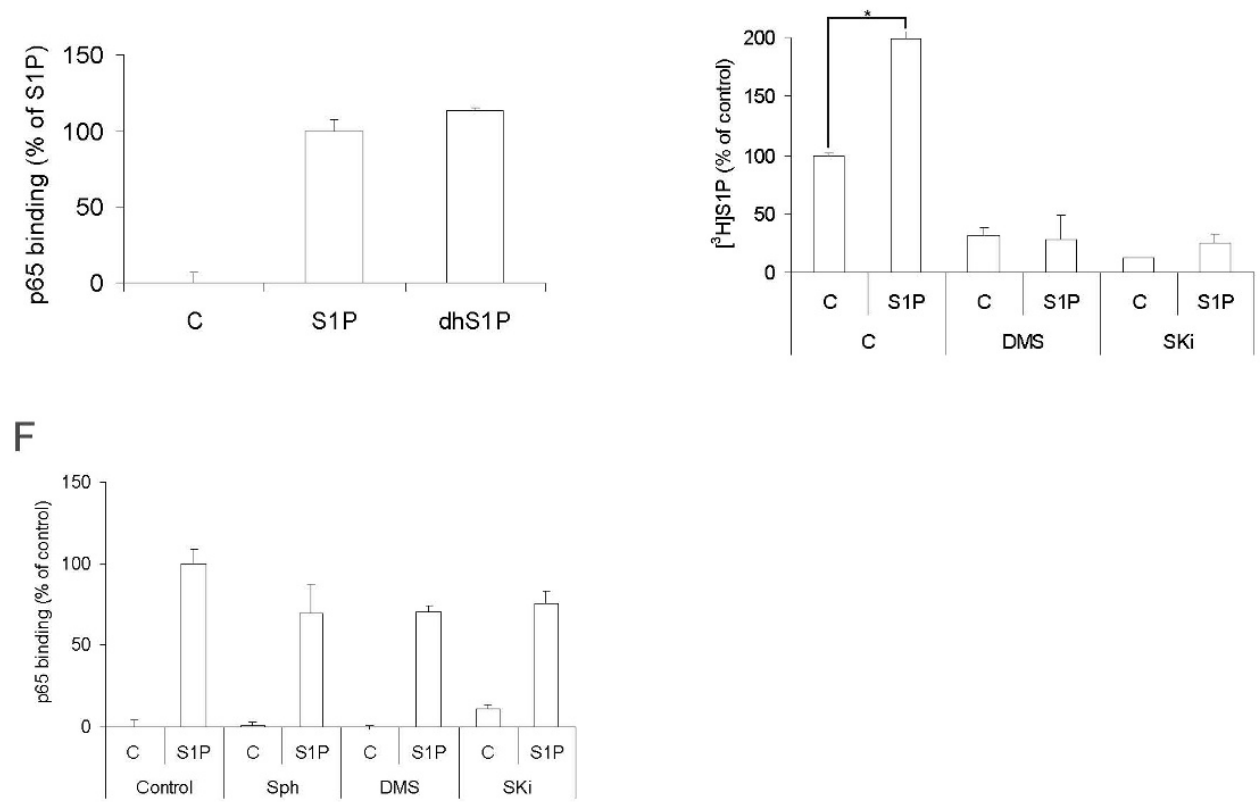

Figure 2 S1P activates NF-KB through G protein coupled receptors. A. The upper panel shows the presence of mRNAs encoding G protein coupled S1P receptors in HeLa cells. + and - denote whether the extracted RNA was reverse transcribed or not. The lower panel shows Western blots of the S1P receptors in HeLa cells stimulated $\pm 3 \mu \mathrm{M}$ S1P for 30 minutes. B. Concentration-response curve for S1P-induced activation of NF-KB (p65). HeLa cells were stimulated with varying concentrations of S1P for 30 minutes. Protein extracts were analyzed by NF-kB (p65) ELISA. $5 \mu \mathrm{g}$ of protein was used from each extract. C. HeLa cells were preincubated with $50 \mathrm{ng} / \mathrm{ml}$ PTX for $16 \mathrm{~h}, 10 \mu \mathrm{M}$ VPC23019 for 30 minutes or $10 \mu \mathrm{M}$ JTE013 for 30 minutes prior to stimulation with $3 \mu \mathrm{M}$ S1P for 30 minutes (left panel), or treated with $\mathrm{S}_{1} \mathrm{P}_{2}$ or S1P 5 siRNA for $48 \mathrm{~h}$ prior to S1P stimulation. Proteins were then extracted and NF-KB (p65)-activation was assayed by ELISA. D. HeLa cells were stimulated with either vehicle, $3 \mu \mathrm{M}$ S1P or $3 \mu \mathrm{M}$ dihydro-S1P for 30 minutes. $5 \mu \mathrm{g}$ of protein from each extract was used for the NF-KB (p65) ELISA. E. HeLa cells were pre-incubated with either vehicle, $10 \mu \mathrm{M}$ DMS or $10 \mu \mathrm{M}$ SKi for 5 minutes. The cells were then stimulated with $3 \mu \mathrm{M}$ S1P for 10 minutes in the presence of $\left[{ }^{3} \mathrm{H}\right]$ sphingosine. The bars show synthesized cellular $\left[{ }^{3} \mathrm{H}\right] \mathrm{S} 1 \mathrm{P}$ as percent of the unstimulated control. $\mathbf{F}$. The cells were pre-incubated either with vehicle, $10 \mu \mathrm{M}$ sphingosine, $10 \mu \mathrm{M}$ DMS or $10 \mu \mathrm{M}$ SKi for 5 minutes. Following a 30-minute stimulation with $3 \mu \mathrm{M} \mathrm{S1P}$, the cells were harvested, lyzed and the DNA-binding activity of p65 was measured from $5 \mu \mathrm{g}$ of protein extract. The data points and bars in panels B-F denote the mean \pm SEM of at least three independent experiments $\left({ }^{*}, p<0.05\right)$. 
A

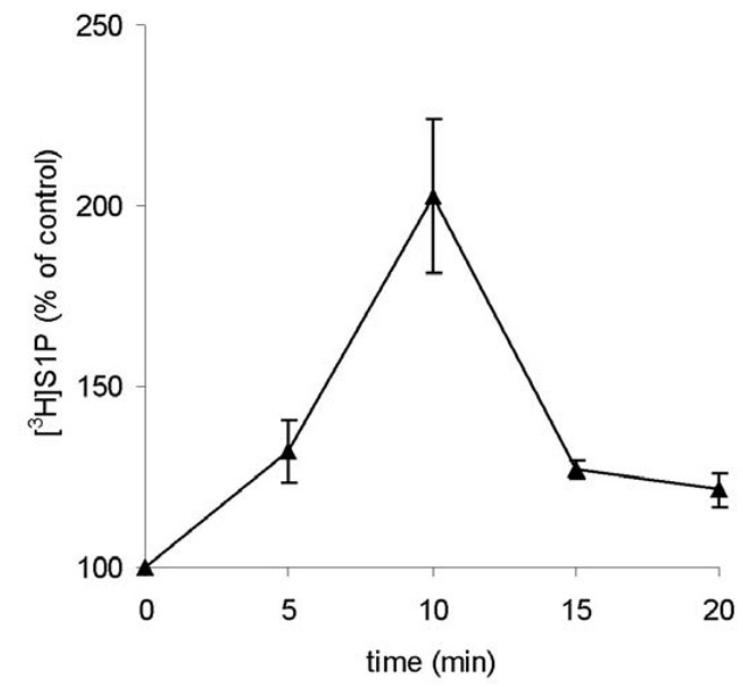

C

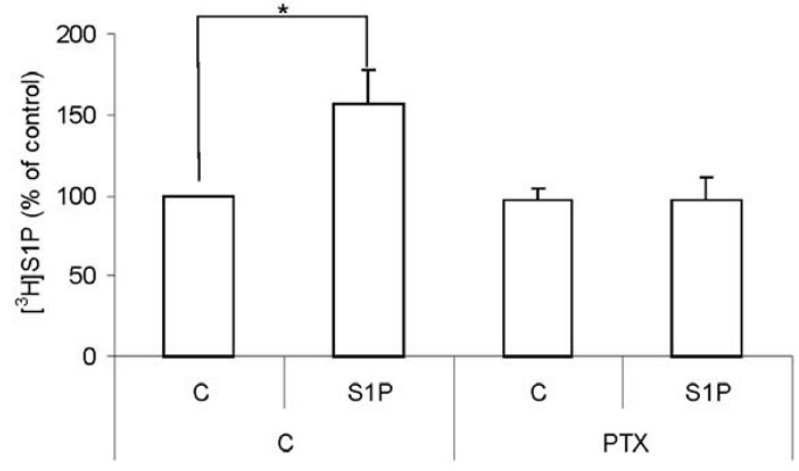

B

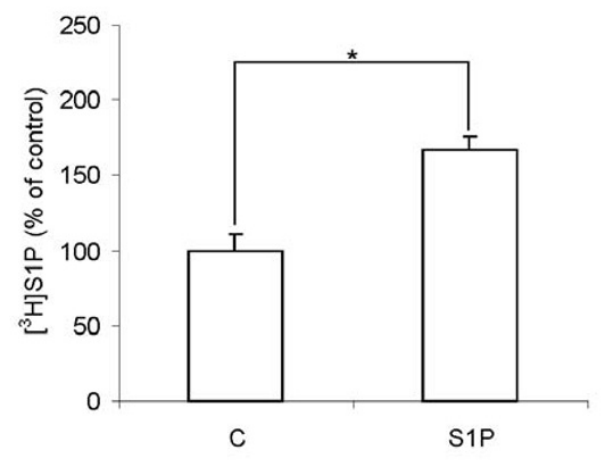

D

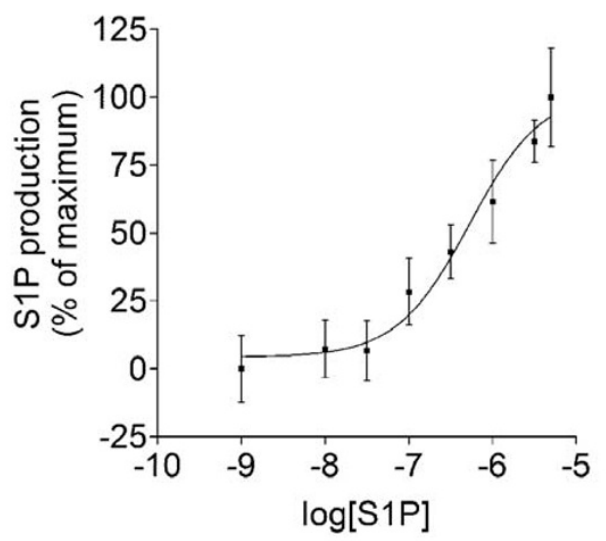

Figure 3 S1P induces cellular S1P-production and -secretion through Gi protein coupled receptors. A. HeLa cells were exposed to either vehicle or $3 \mu \mathrm{M} \mathrm{S1P}$ for the indicated period of times in the presence of $\left[{ }^{3} \mathrm{H}\right]$ sphingosine. The amount of produced $\left[{ }^{3} \mathrm{H}\right] \mathrm{S} 1 \mathrm{P}$ is expressed as percent of that in vehicle-treated cells. B. Secreted [ $\left.{ }^{3} \mathrm{H}\right] \mathrm{S} 1 \mathrm{P}$ was extracted from the cell culture medium following a 10 minute stimulation with vehicle or $3 \mu \mathrm{M}$ S1P, and was analyzed using thin layer chromatography and scintillation counting. $\mathbf{C}$. The cells were treated with $50 \mathrm{ng} / \mathrm{ml}$ pertussis toxin or vehicle for 16 h. Cellular lipids were extracted following a 10 minute stimulation with $3 \mu \mathrm{M} \mathrm{S1P}$ or vehicle in the presence of $\left[{ }^{3} \mathrm{H}\right]$ sphingosine. The formed [3H]S1P was assayed using thin layer chromatography and scintillation counting. D. Concentration-response curve for S1P-induced S1P production. HeLa cells were stimulated with varying concentrations of S1P or vehicle together with [3H]sphingosine for 10 minutes. Cellular lipids were extracted and separated by HPTLC. The results are expressed as percent increased [ $\left.{ }^{3} \mathrm{H}\right] \mathrm{S} 1 \mathrm{P}$ production in S1P stimulated cells compared with control. The data points and bars in panels A-D denote the mean \pm SEM of at least three independent experiments ( $\left.{ }^{*}, p<0.05\right)$.

Pre designad SMARTpool siRNA's were purchased from Dharmacon (Lafayette, CO, U.S.A.).

\section{Cell culture}

HeLa cells and MEL-7 cells were cultured in Dulbecco's modified Eagle's medium supplemented with $10 \%$ fetal bovine serum, $2 \mathrm{mM} \mathrm{L}$-glutamine, and $50 \mathrm{U} / \mathrm{ml}$ penicillin and $50 \mu \mathrm{g} / \mathrm{ml}$ streptomycin at $37^{\circ} \mathrm{C}$ in a water-saturated atmosphere of $5 \% \mathrm{CO}_{2}$ and $95 \%$ air. Cells were cultured in medium with serum replaced by $0.2 \%$ fatty acid free BSA $24 \mathrm{~h}$ prior to experiments. WM35 cells were cultured in
RPMI 1640 supplemented with 10\% fetal bovine serum, 2 $\mathrm{mM} \mathrm{L}$-glutamine, $5 \mu \mathrm{g} / \mathrm{ml}$ insulin, and $50 \mathrm{U} / \mathrm{ml}$ penicillin and $50 \mu \mathrm{g} / \mathrm{ml}$ streptomycin at $37^{\circ} \mathrm{C}$ in a water-saturated atmosphere of $5 \% \mathrm{CO}_{2}$ and $95 \%$ air.

\section{PCR}

RNA was isolated using High Pure RNA Isolation Kit from Roche (Mannheim, Germany). For synthesis of cDNA SuperScript III from Invitrogen (Paisley, Scotland) was used and DynaZyme EXT from FinnZymes (Espoo, Finland) was used for the PCR-reactions. All steps were 




Figure 4 NF-KB activation induced by exogenously added S1P is enhanced by S1P produced by the cells. Cells transfected with control siRNA or SK1 siRNA were treated with the indicated concentrations of S1P for 30 minutes and were analyzed for active NF-KB (p65) using ELISA. The panel to the right shows representative western blots of control and SphK1 siRNA treated cells. The bars denote the mean \pm SEM of at least three independent experiments $\left({ }^{*}, \mathrm{p}<0.05\right)$.

done according to the instructions given by the manufacturers. PCR reactions were performed by first heating the reaction mix to $94^{\circ} \mathrm{C}$ for 5 minutes. This was followed by 29 cycles of 30 seconds at $94^{\circ} \mathrm{C}, 60$ seconds at the annealing temperature and elongation 60 seconds at $72^{\circ} \mathrm{C}$. The primers, annealing temperatures, and product lengths

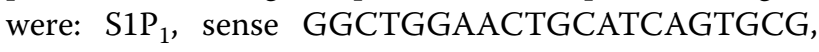
antisense GAGCAGCGCCACATTCTCAGAGC, $60^{\circ} \mathrm{C}$, 223 bp; S1P $\mathrm{P}_{2}$, sense CCGAAACAGCAAGTTCCACT, antisense CCAGGAGGCTGAAGACAGAG, $61^{\circ} \mathrm{C}, 197$ bp; $\mathrm{S} 1 \mathrm{P}_{3}$, sense AAGGCTCAGTGGTTCATCGT, antisense GCTATTGTTGCTGCTGCTTG, 61 ${ }^{\circ} \mathrm{C}, 201 \mathrm{bp}$;

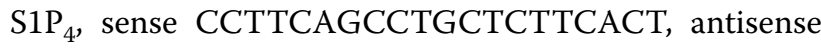
AAGAGGATGTAGCGCTTGGA, $64^{\circ} \mathrm{C}, 223 \mathrm{bp;}$ S1P $_{5}$, sense AGGACTTCGCTTTTGCTCTG, antisense TCTA GAATCCACGGGGTCTG, 59 $\mathrm{C}, 201 \mathrm{bp}$.

\section{S1P-production assay}

Cells (roughly 270000 cells per $35-\mathrm{mm}$ cell culture plate) were incubated over night in medium with serum replaced by $0.2 \%$ fatty acid-free BSA. Cells were then stimulated with agonist or vehicle together with $\left[{ }^{3} \mathrm{H}\right]$ sphingosine $(\sim 200,000 \mathrm{cpm})$ with fatty acid free BSA as carrier. Lipids were extracted by aspirating the culture medium and adding $500 \mu \mathrm{l}$ of ice-cold methanol to the cells. Cells were scraped from the petri dishes and transferred to eppendorf tubes. The tubes were sonicated for 5 minutes and then centrifuged at 6,000 g for 10 minutes to remove cell debris. The supernatant was then transferred to glass vials. S1P was added to each sample for identification and the supernatant was evaporated. For measurements of secreted S1P, $\left[{ }^{3} \mathrm{H}\right] \mathrm{S} 1 \mathrm{P}$ was extracted from the medium as previously described previously [29]. Briefly, $2.2 \mathrm{ml}$ of chloroform: methanol: $\mathrm{HCl}$ (50:50:1) was used to extract S1P from $900 \mu \mathrm{l}$ medium. The organic phase was collected and evaporated. After re-dissolving in methanol the samples were spotted onto HPTLC plates and separated with butan-1-ol: acetic acid: water (3:1:1, v/ v). S1P was stained with ninhydrin and spots were scraped and the formed $\left[{ }^{3} \mathrm{H}\right] \mathrm{S} 1 \mathrm{P}$ was counted using liquid scintillation. From a typical experiment the recovered counts of intracellular and secreted $\left[{ }^{3} \mathrm{H}\right] \mathrm{S} 1 \mathrm{P}$ at basal conditions were $449 \pm 69 \mathrm{cpm}$ and $175 \pm 20 \mathrm{cpm}$, respectively in HeLa cells. Under similar conditions $225 \pm 34 \mathrm{cpm}$ was extracted from MEL-7 cells and $557 \pm 61 \mathrm{cpm}$ from the medium. WM35 cells had a basal cellular $\left[{ }^{3} \mathrm{H}\right] \mathrm{S} 1 \mathrm{P}$ of 213 $\pm 18 \mathrm{cpm}$ and secreted $288 \pm 55 \mathrm{cpm}$.

\section{Construction of a viral vector containing human SphK1 and transduction of HeLa cells}

Human SphK cDNA was cloned and FLAG -tagged at the 3 ' end according to Pitson et al [30]. The SphK-FLAG fragment was PCR amplified by using primers with $5^{\prime}$ $M l u \mathrm{I}$ and 3' SalI sites and cloned into the WPT-GFP lentiviral vector which had been digested with $M l u \mathrm{I}$ and SalI to remove the GFP gene. Lentiviral vectors expressing the SphK-FLAG construct were produced by transient three plasmid cotransfection into HEK 293T cells by using calcium phosphate precipitation. The three plasmid mixture consisted of $14.5 \mu \mathrm{g}$ WPT-SphKFLAG, $8.3 \mu \mathrm{g}$ pCMV $\Delta$ R8.91 and 2.1 $\mu \mathrm{g}$ MD.G (all plasmids were a kind gift from Dr. D. Trono, Lausanne, Switzerland). The virus-containing media were harvested 48 hours later by filtering the media through $0.45 \mu \mathrm{m}$ pore size filter and centrifuging at $16000 \mathrm{~g}$ for $2.5 \mathrm{~h}$ at $+4^{\circ} \mathrm{C}$. The resulting pellets were resuspended in $200 \mu \mathrm{l}$ serum free DMEM. For transduction HeLa cells were plated on 6-well plates $\left(1 \times 10^{5}\right.$ per well $)$ and 24 hours later virus together with 8 $\mu \mathrm{g} / \mathrm{ml}$ Polybrene was added at multiplicity of infection 10 and incubated for 6 hours after which time the medium was replaced with fresh medium.

\section{siRNA mediated knock down}

The cells were grown to $90 \%$ confluency, and transfection was done with N-TER transfection reagent according to the manufacturer's protocol for serum-free transfection with slight modifications. The siRNA was added to the cells at a final concentration of $100 \mathrm{nM}$. Following a 24 hour incubation with the siRNA reagent, the medium was changed to fresh medium containing $0.2 \%$ Fatty acid free BSA. Following another $24 \mathrm{~h}$ incubation the cells were used for experiments.

\section{NF-KB activation assay}

Cells grown on $60 \mathrm{~mm}$ petri dishes were harvested and pelleted in ice cold PBS. The cell pellet was quick-freezed and resuspended in $150 \mu \mathrm{l}$ buffer containing $25 \%$ glycerol, $0.42 \mathrm{M} \mathrm{NaCl}, 1.5 \mathrm{mM} \mathrm{MgCl} 2,0.2 \mathrm{mM}$ EDTA, $20 \mathrm{mM}$ Hepes (pH 7.9), $0.5 \mathrm{mM}$ DTT, and 0.5 mM PMSF. The extract was then centrifuged at $15,000 \times \mathrm{g}$ for 20 minutes 


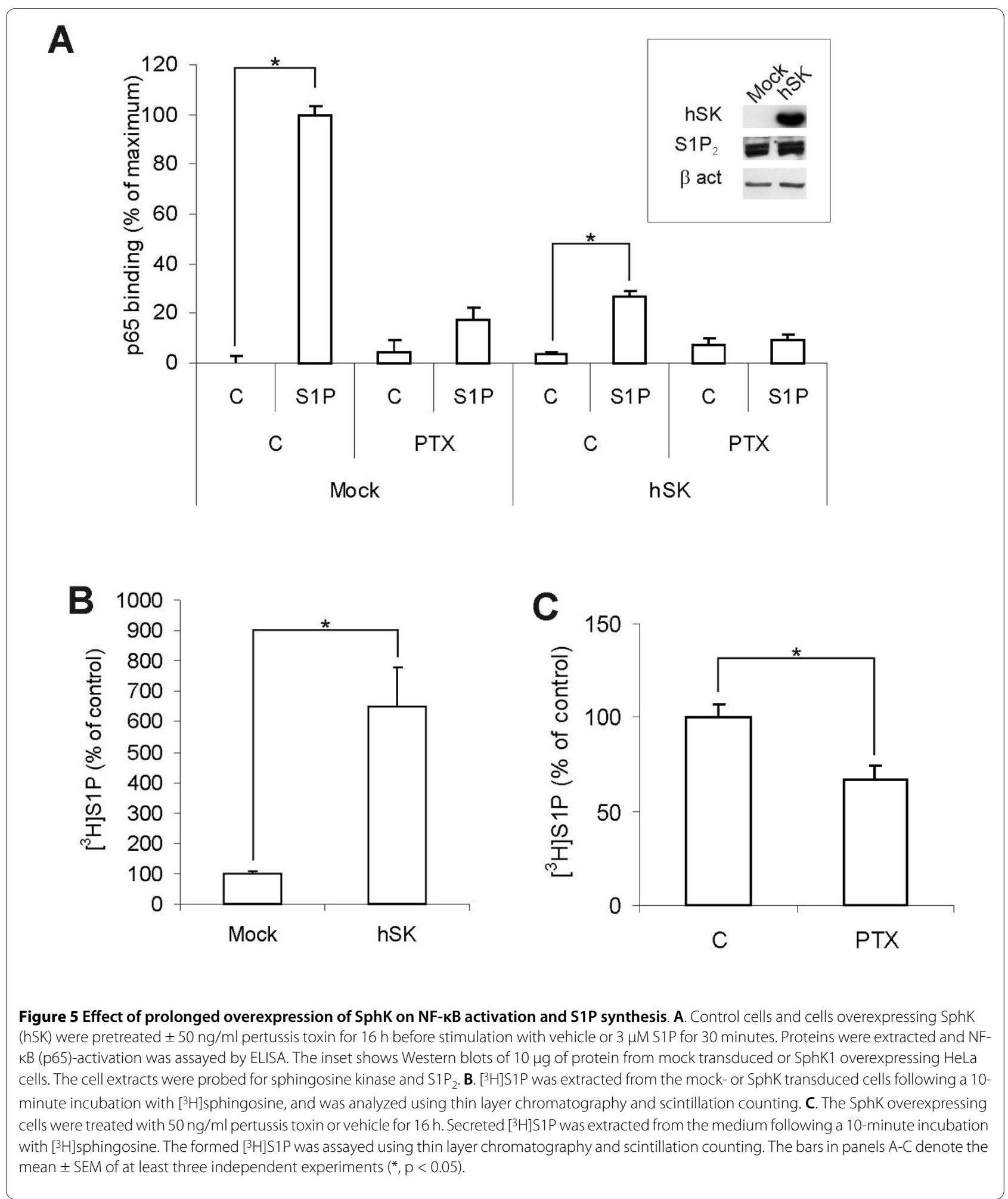

at $+4^{\circ} \mathrm{C}$. The supernatant was collected and protein concentrations were determined. Two methods for assaying NF- $k B$ (p65) DNA-binding activity were used. NFkB transactivation capacity was measured from the extracts either by using a Trans-AM NF- $\mathrm{KB}$ (p65) transcription factor assay kit (Active Motif, Carlsbad, CA) according to the manufacturers' instructions, or by electrophoretic mobility shift assay (EMSA). The results from the TransAM NF- $\mathrm{kB}$ (p65) transcription factor assay kit are presented as percent activation with the stimulated control set to $100 \%$ and the unstimulated control as $0 \%$. This was made to compensate for between-experiment differences in NF- $\mathrm{kB}$ activation. For the EMSA experiments, the consensus NF- $\mathrm{kB}$ binding site (5'-AGCTTCAGAGGG- 
A

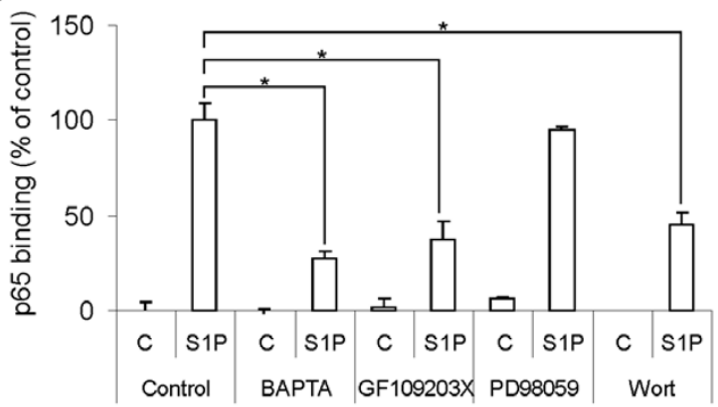

B

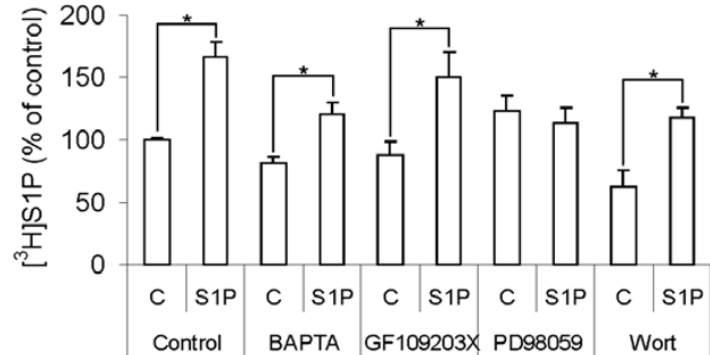

Figure 6 Signaling cascades regulating S1P-induced S1P-production and S1P-induced activation of NF-kB. A. NF- $K B$-activation induced after stimulating HeLa cells for 30 minutes with $3 \mu \mathrm{M} \mathrm{S1P.} \mathrm{The} \mathrm{cells} \mathrm{were} \mathrm{pre-treated} \mathrm{with} 10 \mu \mathrm{M}$ BAPTA-AM for 30 minutes, 50 M PD98059 for 30 min, 1 MM GF109203× for 5 min or 30 nM Wortmannin for 5 minutes. B. The cells were treated with inhibitors the same way as in A. Following a 10-minute stimulation with 3 MM S1P or vehicle together with $\left[{ }^{3} \mathrm{H}\right]$ sphingosine, lipids were extracted and the produced $\left[{ }^{3} \mathrm{H}\right] \mathrm{S} 1 \mathrm{P}$ was measured by thin layer chromatography and scintillation counting. The bars in A and B denote the mean \pm SEM of at least three independent experiments (*, $p<0.05$ ).

GACTTTCCGAGAGG-3') was 32P-labeled. ProteinDNA complexes were separated on a native $4 \%$ polyacrylamide gel. The gel was dried and exposed to autoradiography film over night. Both methods measure NF-kB activity by detecting it binding to its consensus binding sequence.

\section{Apoptosis assay}

Cells were assayed using an active caspase- 3 detection kit from BD Pharmingen according to the manufacturers' instructions. In brief, cells were collected in eppendorf tubes, spun down and washed twice in $1 \mathrm{ml}$ PBS. The cells were resuspended in $150 \mu$ l Cytofix/Cytoperm ${ }^{\mathrm{Tm}}$ Solution. Following a 20 minute incubation on ice the cells were washed twice with $0.5 \mathrm{ml}$ Perm/Wash ${ }^{\mathrm{Tm}}$ Buffer. The cells were then incubated with the phycoerythrinlabelled antibody against active caspase-3 (1:20 in $100 \mu \mathrm{l}$ Perm/Wash ${ }^{\mathrm{TM}}$ Buffer). The cells were washed once in $1 \mathrm{ml}$ Perm/Wash ${ }^{\mathrm{TM}}$ Buffer. The cells were resuspended in $0.5 \mathrm{ml}$ Perm/Wash ${ }^{\text {тм }}$ Buffer and were then analyzed by flowcytometry using a BD FACScan and Cell Quest software.

\section{Western blotting}

$35 \mathrm{~mm}$-petri dishes were washed once with cold HBSS, and scraped in $70 \mu$ lysis buffer $(10 \mathrm{mM}$ Tris/ $\mathrm{HCl}(\mathrm{pH}$ 7.7), $150 \mathrm{mM} \mathrm{NaCl}, 7 \mathrm{mM}$ EDTA, 0.5\% NP-40, $0.2 \mathrm{mM}$ PMSF, and $0.5 \mu \mathrm{g} / \mathrm{ml}$ leupeptin). Lysates were kept on ice for 15 minutes and were then centrifuged at 10,000 $\mathrm{g}$ for 15 minutes. $3 \times$ Laemmli's buffer was mixed with the supernatant and the solution was heated to $95^{\circ} \mathrm{C}$ for 3 minutes. Proteins were separated by $10 \%$ SDS-PAGE and transferred onto a nitrocellulose membrane. The primary antibodies used were anti-Bcl- $\mathrm{x}_{\mathrm{L}}$ from Santa Cruz (CA, U.S.A.) and anti-Hsc70 from Stressgen (Victoria, Canada). HRP conjugated secondary antibodies were used, and bands were exposed on film by chemiluminescence.

\section{Statistics}

Results are expressed as means \pm SEM from a minimum of three independent experiments. Statistical analysis was made using Student's $t$ test for paired observations. When three or more means were tested, one way ANOVA was performed followed by Dunnett's test for multiple comparisons against a single control. Statistical significance $(\mathrm{p}<0.05)$ is denoted with *.

\section{Results}

\section{S1P stimulates NF-кB dependent cell survival}

It has been firmly established that S1P is a cytoprotective agent. However, the downstream mechanisms are pleiotropic and have only been partially identified. To study the S1P-induced survival signaling pathways we first needed to identify a reproducible and quantifiable endpoint. NF- $\mathrm{KB}$ is a well-defined survival factor, and there are reports showing that $\mathrm{S} 1 \mathrm{P}$ activates $\mathrm{NF}-\mathrm{kB}$ by signaling through G-protein coupled S1P receptors [31-33]. NF-kB activation was therefore ideal to use as an endpoint for addressing S1P signaling pathways leading to survival. In our initial experiments, we could confirm the importance of NF- $\mathrm{kB}$ in S1P mediated survival signaling. S1P protected HeLa cells from Fas ligand-induced apoptosis in an NF- $\mathrm{k}$ dependent manner (Figure 1A, B). S1P also induced an upregulation of the anti-apoptotic protein Bcl-xL which was blocked by the NF-kB inhibitor Bay 117082 (Figure 1C).

\section{S1P activates NF-kB through G protein coupled receptors}

$\mathrm{S} 1 \mathrm{P}$ induces most of its functions by activating $\mathrm{G}$ protein coupled S1P receptors, but an intracellular mode of action has been proposed to take place in some cases. We therefore addressed the site of action for S1P-induced NF- $\mathrm{kB}$ activation in HeLa cells. The receptors $\mathrm{S}_{1} \mathrm{P}_{1-3}$ and $\mathrm{S} \mathrm{P}_{5}$ were detectable by PCR and Western blot in HeLa 
A

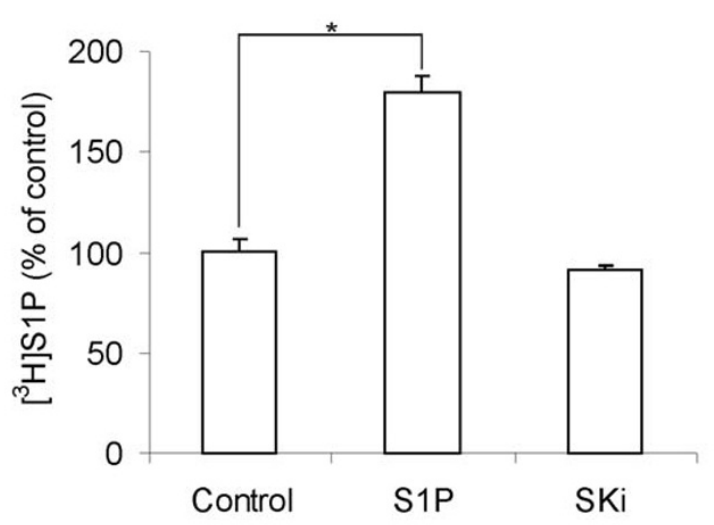

C

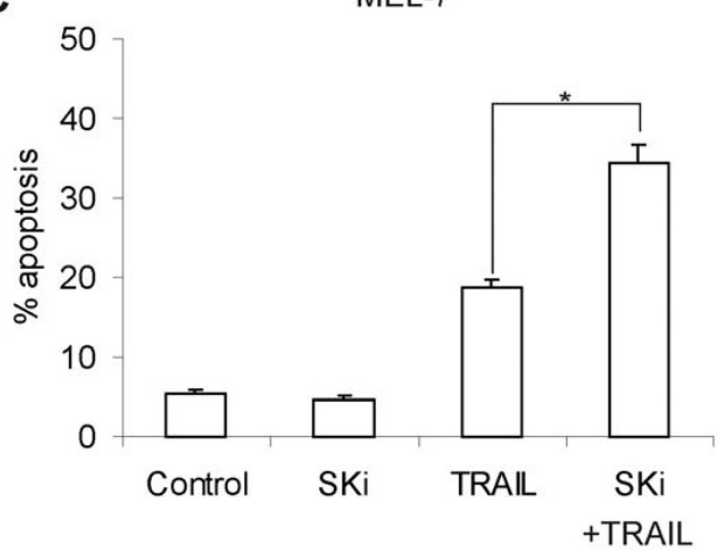

B MEL-7

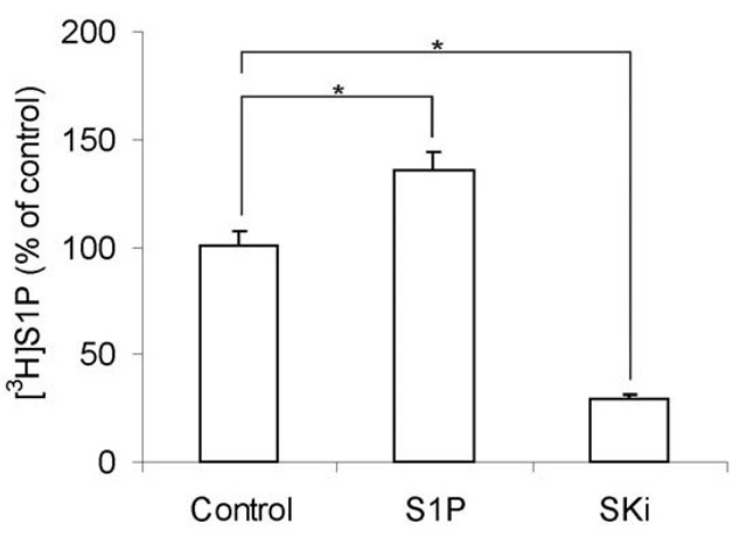

D

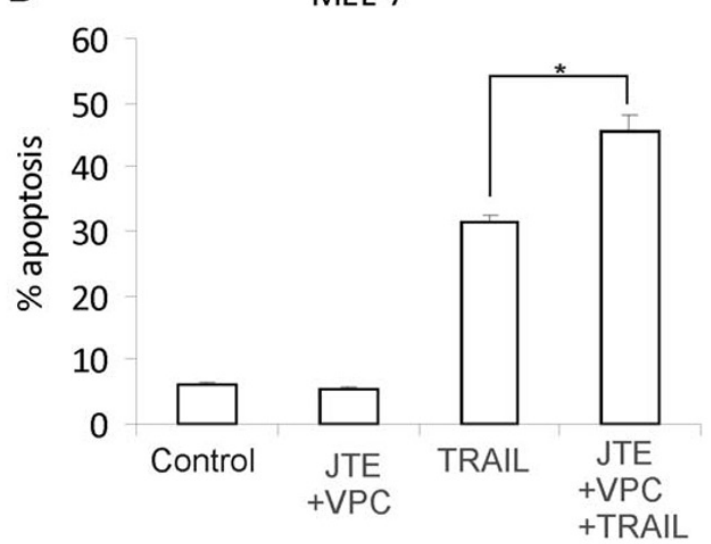

Figure 7 S1P-induced secretion of S1P in the malignant tumor cell lines MEL-7 and WM35. WM35 (A.) or MEL-7 (B.) cells were exposed to either vehicle, $3 \mu \mathrm{M} \mathrm{S1P}$ or $10 \mu \mathrm{M}$ SKi for 10 minutes in the presence of [3H]sphingosine. Secreted [3H]S1P was then extracted from the cell culture medium and analysed by HPTLC. C. MEL-7 cells were treated with $10 \mu \mathrm{M}$ SKi or vehicle for $4 \mathrm{~h}$. Apoptosis was then induced by addition of $100 \mathrm{ng} / \mathrm{ml}$ Tumor necrosis factor-related apoptosis-inducing ligand (TRAIL) for 4 h. D. MEL-7 cells were treated with vehicle or 10 MM JTE013 and VPC23019 for 4 h. Apoptosis was induced by addition of TRAIL for $4 \mathrm{~h}$, and cells positive for cleaved caspase-3 was measured using FACS. The bars in panels A-D denote the mean \pm SEM of three independent experiments $\left(^{*}, p<0.05\right)$.

cells (Figure 2A). S1P induced NF-kB activation with an $\mathrm{EC}_{50}$ of $88 \mathrm{nM}$, which is consistent with a $\mathrm{G}$ protein coupled receptor -mediated effect (Figure 2B). Furthermore, the S1P-induced NF- $\mathrm{BB}$ activation was attenuated by the $G_{i}$ inhibitor pertussis toxin, by the $\mathrm{S}_{1} \mathrm{P}_{2}$ antagonist JTE013, and in $\mathrm{S}_{1} \mathrm{P}_{2}$ siRNA treated cells (Figure $2 \mathrm{C}$ ). The $\mathrm{S} 1 \mathrm{P}_{1 / 3}$ antagonist VPC 23019 did not inhibit the S1P induced $\mathrm{NF}_{\kappa} \mathrm{B}$ activation indicating that the effect is not dependent on $\mathrm{S}_{1} \mathrm{P}_{1}$ or $\mathrm{S}_{3} \mathrm{P}_{3}$ (Figure $2 \mathrm{C}$ ). In addition, dihydro-S1P potently activated NF- $\mathrm{BB}$ (Figure 2D). Dihydro-S1P binds and activates $G$ protein coupled S1P receptors and has often been used as a negative control for intracellular effects of S1P [34,35]. Taken together, these results show that the S1P induced activation of NF$\mathrm{\kappa B}$ is mediated through an extracellular mode of action. It is known that extracellular S1P can cause cells to increase their intracellular production of S1P $[17,18]$. To exclude the possibility that intracellularly produced S1P was responsible for the NF- $\mathrm{kB}$ response, we measured the activation of NF- $\mathrm{kB}$ in cells treated with sphingosine kinase inhibitors. The cells were stimulated with $3 \mu \mathrm{M}$ S1P to saturate G-protein coupled S1P receptors and to achieve maximal NF- $\kappa$ B activation (see Figure $2 B$ ). Under these conditions, the sphingosine kinase inhibitors DMS and SKi effectively blocked both the basal and agonistinduced S1P-production (Figure 2E). However, the NF$\mathrm{\kappa B}$ activation induced by extracellular S1P was not significantly affected (Figure 2F). These observations are in line with earlier studies [31-33] showing that S1P-induced NF- $\mathrm{kB}$-activation is mediated through GPCR's. 
NF-kB activation induced by exogenously added S1P is enhanced by S1P produced and secreted by the cells

Extracellularly added S1P induced a transient increase in cellular S1P-production (Figure 3A), accompanied by an increased secretion of S1P (Figure 3B). The S1P-induced $\mathrm{S} 1 \mathrm{P}$-production was inhibited by pertussis toxin, suggesting dependence on GPCR-signaling (Figure 3C). The S1P induced S1P-production displayed a saturable concentration response curve, with a noticeable response following stimulation with $100 \mathrm{nM}$ extracellular S1P (Figure 3D). There are now several reports showing that intracellularly produced S1P can be exported and act on cells in an autocrine or paracrine fashion [24-26]. Since extracellular S1P stimulated the cells' own production and secretion of S1P, we hypothesized that this could constitute a self amplifying signaling mechanism. When cells are stimulated with high concentrations of extracellular S1P, such a mechanism will not be noticeable, since all S1P-receptors will be saturated and not affected by any additional S1P that is secreted from the cells. However, if non-saturating concentrations of S1P are added to the cells, endogenously produced and secreted S1P might have an enhancing effect. To test this hypothesis we did concentrationresponse measurements for S1P-induced NF-kB activation with or without sphingosine kinase inhibition. A higher concentration of extracellular S1P was needed to achieve half-maximal NF-кB-activation in SphK1 siRNA treated cells compared to control cells (Figure 4). In additional experiments we found that there was a shift in the $\mathrm{EC}_{50}$ value from $74 \mathrm{nM}$ in control cells (comparable to the $88 \mathrm{nM}$ in figure $2 \mathrm{~B}$ ) to $158 \mathrm{nM}$ in cells treated with $10 \mu \mathrm{M}$ DMS. This shift is large enough to be significant for Gprotein signaling, i.e. at the $\mathrm{EC}_{50}$ concentration, approximately half of the activating S1P is of cellular origin. Taken together, these results are in support of a model where S1P signaling is amplified through an autocrine feed-forward loop.

\section{Effect of prolonged overexpression of SphK on NF-KB activation and S1P synthesis}

Next, we performed studies on cells overexpressing SphK1. A lentivirus based system was utilized for overexpressing human SphK1 in HeLa cells. Extracellular S1P efficiently activated NF- $\mathrm{kB}$ in mock-transduced cells. This activation was blocked by $\mathrm{G}_{\mathrm{i}}$ protein inhibition, confirming the dependence on GPCR-signaling. Interestingly, in cells overexpressing SphK1, exogenous S1P only weakly activated NF-kB (Figure 5A). The cellular level of the receptor $\mathrm{S}_{1} \mathrm{P}_{2}$ was not affected by SphK1 overexpression (Figure $5 \mathrm{~A}$ inset), suggesting that this observation is likely explained by homologous desensitization of $\mathrm{S}_{2} \mathrm{P}_{2}$ receptors without subsequent receptor degradation as shown by Jolly et al [36]. Since the NF-kB activation was mediated through $\mathrm{G}$ protein coupled S1P-receptors and independent of an intracellular action of S1P, these results seem to confirm that autocrine S1P modulates NF-кB signaling. Cells overexpressing SphK had an elevated basal S1P production of $650 \pm 130 \%$ compared to control cells (Figure 5B). Treating the SphK overexpressing cells with pertussis toxin for $16 \mathrm{~h}$ lead to a significant decrease in the amount of secreted S1P (Figure 5C), which is in line with an autocrine feed-forward loop upholding the production and secretion of S1P.

\section{Signaling cascades regulating S1P-induced S1P-production} and S1P-induced activation of NF-KB

PKC, phosphatidyl-inositol 3-kinase (PI3K), mitogen activated protein kinase (MAPK) and $\mathrm{Ca}^{2+}$ are effectors known to act downstream of S1P-receptors. We therefore compared the roles of these signaling components in $\mathrm{S} 1 \mathrm{P}$-induced activation of $\mathrm{NF}-\mathrm{kB}$ and in S1P-induced $\mathrm{S} 1 \mathrm{P}$-production. The intracellular $\mathrm{Ca}^{2+}$ chelator BAPTAAM, the PKC inhibitor GF109203× and the PI3K inhibitor wortmannin attenuated the S1P-induced NF-kB-activation, whereas the MAPK-kinase (MEK) inhibitor PD98059 was without an effect (Figure 6A). The S1Pinduced increase in cellular S1P-production was completely blocked by PD98059, slightly reduced by $\mathrm{Ca}^{2+}$ chelation, and not significantly affected by neither GF109203× nor wortmannin, (Figure 6B). These results are in accordance with previous findings that ERK1/2 and $\mathrm{Ca}^{2+}$ are important factors for activating and translocating SphK to the plasma membrane respectively $[19,20]$. These results illustrate that S1P utilizes different signaling pathways to induce activation of NF- $\mathrm{kB}$ and to stimulate S1P-production.

\section{S1P-induced secretion of S1P in the malignant tumor cell lines MEL-7 and WM35}

We used the two malignant melanoma cell lines MEL-7 and WM35 to test whether our proposed self-amplifying autocrine loop is also present in other than HeLa cells. In both cell lines, the secretion of S1P was enhanced by the addition of exogenous S1P (Figure 7A, B). This suggests that the described self-amplifying autocrine signaling is common also in other types of tumor cells. Since the MEL-7 cells displayed a higher basal secretion of S1P (results not shown), we tested whether sphingosine kinase was involved in survival signaling in this cell line. We found that inhibition of sphingosine kinase per se did not render the tumor cells apoptotic, but sensitized them to apoptosis induced by TRAIL (Figure 7C), a selective inducer of death in many transformed cells but not in most normal cells. To address whether this effect was due to secreted S1P, we repeated the experiment in cells treated with JTE013 and VPC23019 to block signaling via $\mathrm{S}_{1} \mathrm{P}_{1-3}$ (Figure 7D). Similar to what was observed in cells treated with SKi, the receptor antagonists alone did not affect apoptosis, but increased the potency of TRAIL to 
induce cell death. This indicates that the observed effect is due to S1P secretion rather than an intracellular mode of action. Down-regulation of the self-amplifying S1P signaling in combination with TRAIL treatment is therefore potentially useful in cancer therapy.

\section{Discussion}

Our knowledge regarding how sphingolipids regulate cell survival or death has been rapidly increasing since the concept of a sphingolipid "rheostat" was first introduced. S1P has emerged as a central bio-active lipid with both intracellular and extracellular actions. There is some controversy surrounding sphingolipids and their sites of action in survival signaling. Since one type of sphingolipid may be rapidly converted into another sphingolipid with opposite effects on survival, it has proven difficult to determine to which extent each lipid-type is responsible for the outcome of the signaling. In the present report we show that S1P antagonizes death receptor-induced apoptosis in HeLa cells by acting through G protein-coupled S1P receptors and activating the transcription factor NF$\kappa B . \mathrm{S}_{2} \mathrm{P}_{2}$ was at least in part responsible for activating NF$\kappa \mathrm{B}$, but it seems likely that S1P promotes survival through simultaneous activation of several signaling cascades. It has previously been shown that S1P may activate NF- $\mathrm{kB}$ through $\mathrm{S}_{1} \mathrm{P}_{2}$ and $\mathrm{S}_{1} \mathrm{P}_{3}$ in a PLC/PKC-dependent manner [32]. We could confirm that the activation was dependent on PKC and on $\mathrm{S}_{2} \mathrm{P}_{2}$ in HeLa cells. The PI3K inhibitor wortmannin also attenuated the S1P-induced activation of NF- $\mathrm{KB}$, in accordance with what has been shown in vascular smooth muscle cells [37].

It was first shown by Meyer zu Heringdorf et al [17], and later by us [18] that S1P may stimulate its own intracellular synthesis, but whether this also leads to an increase in S1P-secretion has not been previously investigated. We show here that S1P not only stimulates the production of intracellular S1P, but also its secretion. Based on concentration response curves for the S1P-induced NF- $\kappa B$ activation in figure 4 , we conclude that the secreted S1P is an important contributing factor in S1P signaling. The S1P-induced S1P-synthesis was sensitive to MEK-inhibition, but not to inhibition of PKC or PI3K. The opposite was true for S1P-induced NF- $\mathrm{kB}$-activation, which suggests that these two mechanisms can be regulated independently of each other. This was further illustrated by the fact that the $\mathrm{S}_{1} \mathrm{P}_{2}$ antagonist JTE013, and $\mathrm{S}_{1} \mathrm{P}_{2}$ knockdown attenuated the S1P-induced activation of NF- $\mathrm{BB}$, while the S1P-induced S1P-production was unaffected. In conclusion, the results we present here lend support to a novel feed-forward mechanism, with S1P stimulating its own synthesis and secretion. The secreted S1P may then protect the tumor cells from death receptor-induced apoptosis by contributing to NF- $\mathrm{kB}$ activation. An important consequence of the autocrine feed-forward signaling is that an initially small increase in the cells' S1P-production can be considerably amplified. The secreted S1P provides protection for the tumor cell itself, and may also activate a similar feed-forward mechanism in surrounding cells. In addition to stimulating cell survival, S1P also induces cell proliferation [38] and angiogenesis [39]. These factors are crucial for tumor development and metastasis.

\section{Conclusions}

S1P protects HeLa cells from FasL-evoked apoptosis in an NF-kB-dependent manner. We propose that this effect is mediated by a cytoprotective mechanism involving an amplification loop where S1P stimulates its own production and secretion by activating G protein coupled S1Preceptors. It is likely that the mechanism presented here is important for tumor progression.

\section{Acknowledgements}

This work was supported by grants from the Oskar Öflund Foundation (TB), the Sigrid Juselius Foundation (KT, JEE), The Liv och Hälsa Foundation (KT), Svenska Kulturfonden (KT) and the Academy of Finland (TB, JEE, KT). The study was done as a part of the Receptor Structure and Function program at the University of Turku, Åbo Akademi University and the National Public Health Institute, and as a part of the Center of Excellence in Cell stress consortium at Åbo Akademi University. Tomas Blom, Annika Meinander and Nina Bergelin were supported by the Turku Graduate School of Biomedical Sciences during this work. The funding bodies had no role in in study design, data collection, analysis, interpretation, in writing the manuscript, or in the decision to submit the paper for publication.

\section{Abbreviations \\ S1P: sphingosine-1-phosphate; NFkB: nuclear factor kB; SphK: Sphingosine kinase; DMS: N,N-dimethylsphingosine; SKi: 2-( $p$-Hydroxyanilino)-4-( $p$-chloro-} phenyl)thiazole.

\section{Authors' contributions}

TB, JEE and KT planned the experiments; TB, NB, AM and CL performed experiments, JPS contributed with analytical methods and reagents; TB, JEE and KT wrote the paper. All Authors read and approved the final manuscript.

\section{Author Details}

1Department of Biology, Åbo Akademi University, 20520 Turku, Finland, 2Department of Biochemistry and Pharmacy, Åbo Akademi University, 20520 Turku, Finland, ${ }^{3}$ Turku Centre for Biotechnology, Åbo Akademi University \& University of Turku, 20520 Turku, Finland, 4The Minerva Foundation Institute for Medical Research, 00290 Helsinki, Finland, ${ }^{5}$ Current Address: Institute of Biomedicine, University of Helsinki, 00290 Helsinki, Finland and ${ }^{6}$ Current Address: Breakthrough Toby Robbins Breast Cancer Research Centre, Institute of Cancer Research, London SW3 6JB, UK

Received: 17 September 2009 Accepted: 24 June 2010 Published: 24 June 2010 


\section{References}

1. Taha TA, Argraves KM, Obeid LM: Sphingosine phosphate receptors: receptor specificity versus functional redundancy. Biochim Biophys Acta 2004, 1682:48-55

2. Futerman $\mathrm{AH}$ : The complex life of simple sphingolipids. EMBORep 2004, 5:777-782.

3. Sanchez T, Hla T: Structural and functional characteristics of S1P receptors. J Cell Biochem 2004, 92:913-922

4. Balthasar S, Samulin J, Ahlgren H, Bergelin N, Lundquist M, Toescu EC, Eggo MC, Törnquist K: Sphingosine 1-phosphate receptor expression profile and regulation of migration in human thyroid cancer cells. Biochem J 2006, 398:547-556.

5. Waters CM, Long J, Gorshkova I, Fujiwara Y, Connell M, Belmonte KE, Tigyi G, Natarajan V, Pyne S, Pyne NJ: Cell migration activated by plateletderived growth factor receptor is blocked by an inverse agonist of the Sphingosine 1-phosphate receptor-1. FASEB J 2006, 20:509-511.

6. Goparaju SK, Jolly PS, Watterson KR, Bektas M, Alvarez S, Sarkar S, Mel L, Ishii I, Chun J, Milstien S, Spiegel S: The S1P2 receptor negatively regulates platelet-derived growth factor-induced motility and proliferation. Mol Cell Biol 2005, 25:4237-4249.

7. Grey A, Chen Q, Callon K, Xu X, Reid IR, Cornish J: The phospholipids sphingosine-1-phosphate and lysophosphatidic acid prevent apoptosis in osteoblastic cells via a signaling pathway involving G(i) proteins and phosphatidylinositol-3kinase. Endocrinology 2002, 143:4755-4763.

8. Meyer zu Heringdorf D, Liliom K, Schaefer M, Danneberg K, Jaggar JH, Tigyi G, Jakobs KH: Photolysis of intracellular caged sphingosine-1phosphate causes $\mathrm{Ca}^{2+}$ mobilization independently of G-proteincoupled receptors. FEBS Lett 2003, 554:443-449.

9. Ghosh TK, Bian J: Sphingosine 1-phosphate generated in the endoplasmic reticulum membrane activates release of stored calcium. J Biol Chem 1994, 269:22628-22635.

10. Hait NC, Allegood J, Maceyka M, Strub GM, Harikumar KB, Singh SK, Luo C, Marmorstein R, Kordula T, Milstien S, Spiegel S: Regulation of histone acetylation in the nucleus by sphingosine-1-phosphate. Science 2009, 325:1254-1257.

11. Liao J-J, Huang M-C, Graler M, Huang Y, Qiu H, Goetzl EJ: Distinctive T cellsuppressive signals from nuclearized type 1 sphingosine 1-phosphate G-protein coupled receptors. J Biol Chem 2007, 282:1964-1972.

12. Goetzl EJ, Wang W, McGiffert C, Liao JJ, Huang MC: Sphingosine 1phosphate as an intracellular messenger and extracellular mediator in immunity. Acta Pediatr Supp/ 2007, 96:49-52.

13. Kleuser B, Maceyka M, Spiegel S: Stimulation of nuclear sphingosine kinase activity by platelet-derived growth factor. FEBS Lett 2001 503:85-90.

14. Edsall LC, Pirianov GG, Spiegel S: Involvement of sphingosine 1phosphate in nerve growth factor-mediated neuronal survival and differentiation. J Neurosci 1997, 17:6952-6960.

15. Osawa Y, Banno Y, Nagaki M, Brenner DA, Naiki T, Nozawa Y, Nakashima S, Moriwaki H: TNF-alpha-induced sphingosine 1-phosphate-induced activation of phosphatidylinositol 3-kinase/Akt pathway in human hepatocytes. J Immunol 2001, 167:173-180.

16. Billich A, Bornancin F, Mechtcheriakova D, Natt F, Huesken D, Baumruke $\mathrm{T}$ : Basal and induced sphingosine kinase 1 activity in A549 carcinoma cells: function in cell survival and IL-1 beta and TNF-alpha induced production of inflammatory mediators. Cell Signal 2005, 17:1203-1217.

17. Meyer zu Heringdorf D, Lass H, Kuchar I, Lipinski M, Alemany R, Rumenapp $U$, Jakobs KH: Stimulation of intracellular sphingosine-1-phosphate production by G-protein-coupled sphingosine-1-phosphate receptors. Eur J Pharmacol 2001, 414:145-154.

18. Blom T, Slotte JP, Pitson SM, Törnquist K: Enhancement of intracellular sphingosine-1-phosphate production by inositol 1,4,5-trisphosphateevoked calcium mobilization in HEK-293 cells: endogenous sphingosine-1-phosphate as a modulator of the calcium response. Cell Signal 2005, 17:827-836

19. Pitson SM, Moretti PA, Zebol JR, Lynn HE, Xia P, Vadas MA, Wattenberg BW: Activation of sphingosine kinase 1 by ERK1/2-mediated phosphorylation. EMBO J 2003, 22:5491-5500.

20. Sutherland CM, Moretti PA, Hewitt NM, Bagley CJ, Vadas MA, Pitson SM: The calmodulin-binding site of sphingosine kinase and its role in agonist-dependent translocation of sphingosine kinase 1 to the plasma membrane. J Biol Chem 2006, 281:11693-11701.

21. Young KW, Willets JM, Parkinson MJ, Bartlett P, Spiegel S, Nahorski SR, Chaliss RA: $\mathrm{Ca}^{2+} /$ calmodulin-dependent translocation of sphingosine kinase: role in plasma membrane relocation but not activation. Cell Calcium 2003, 33:119-128.

22. Stahelin RV, Hwang JH, Kim J-H, Park Z-Y, Johnson KR, Obeid LM, Cho W The mechanism of membrane targeting of human sphingosine kinase 1. J Biol Chem 2005, 280:43030-43038.

23. Delon C, Manifava M, Wood E, Thompson D, Krugmann S, Ktistakis NT: Sphingosine kinase 1 is an intracellular effector of phosphatidic acid. J Biol Chem 2004, 279:44763-44764.

24. Anelli V, Bassi R, Tettamanti G, Viani P, Riboni L: Extracellular release of newly synthesized sphingosine-1-phosphate by cerebellar granule cells and astrocytes. J Neurochem 2005, 92:1204-1215.

25. Weigert A, Johann AM, von Knethen A, Schmidt H, Geisslinger G, Brune B: Apoptotic cells promote macrophage survival by releasing the antiapoptotic mediator sphingosine-1-phosphate. Blood 2006, 108:1635-1642

26. Kim RH, Takabe K, Milstien S, Spiegel S: Export and functions of sphingosine-1-phosphate. Biochim Biophys Acta 2009, 1791:692-696.

27. Ancellin N, Colmont C, Su J, Li Q, Mitterreder N, Chae SS, Stefansson S, Liau G, Hla T: Extracellular export of sphingosine kinase-1 enzyme. Sphingosine 1-phosphate generation and the induction of angiogenic vascular maturation. J Biol Chem 2002, 277:6667-6675

28. Venkataraman K, Thangada S, Michaud J, Oo ML, Ai Y, Lee YM, Wu M, Parikh NS, Khan F, Proia RL, Hla T: Extracellular export of sphingosine kinase-1a contributes to the vascular S1P gradient. Biochem J 2006 , 397:461-471.

29. Johnson KR, Becker KP, Faccinetti MM, Hannun YA, Obeid LM: PKC dependent activation of sphingosine kinase 1 and translocation to the plasma membrane. Extracellular release of sphingosine-1-phosphate induced by phorbol 12-myristate 13-acetate (PMA). J Biol Chem 2002, 277:35257-35262

30. Pitson SM, Moretti PA, Zebol JR, Xia P, Gamble JR, Vadas MA, D'Andrea RJ, Wattenberg BW: Expression of a catalytic inactive sphingosine kinase mutant blocks agonist-induced sphingosine kinase activation. A dominant-negative sphingosine kinase. J Biol Chem 2000, 275:33945-33950

31. Shatrov VA, Lehmann V, Chouaib S: Sphingosine-1-phosphate mobilizes intracellular calcium and activates transcription factor NF-kappa B in U937 cells. Biochem Biophys Res Commun 1997, 234:121-124.

32. Siehler S, Wang Y, Fan X, Windh RT, Manning DR: Sphingosine 1phosphate activates nuclear factor-kappa B through Edg receptors. Activation through Edg-3 and Edg-5, but not Edg-1, in human embryonic kidney 293 cells. J Biol Chem 2001, 276:48733-48739.

33. Ki SH, Choi MJ, Lee CH, Kim SG: $\mathrm{Ga}_{12}$ specifically regulates COX-2 induction by sphingosine 1-phosphate. J Bio/ Chem 2007 282:1938-1947.

34. Wang F, Van Brocklyn JR, Hobson JP, Movafagh S, Zukowska-Grojec Z, Milstien S, Spiegel S: Sphingosine 1-phosphate stimulates cell migration through a G(i)-coupled cell surface receptor. Potential involvement in angiogenesis. J Bio Chem 1999, 274:35343-35350.

35. Katsuma S, Hada Y, Ueda T, Shiojima S, Hirasawa A, Tanoue A, Takagaki K, Ohgi T, Yano J, Tsujimoto G: Signalling mechanisms in sphingosine 1 phosphate-promoted mesangial cell proliferation. Genes Cells 2002 7:1217-1230.

36. Jolly PS, Bektas M, Watterson KW, Sankala H, Payne SG, Milstien S, Spiege S: Expression of SphK1 impairs degranulation and motility of RBL-2H3 mast cells by desensitizing S1P receptors. Blood 2005, 105:4736-4742

37. Hsieh HL, Wu CB, Sun CC, Liao CH, Lau YT, Yang CM: Sphingosine-1phosphate induces COX-2 expression via PI3K/Akt and p42/p44 MAPK pathways in rat vascular smooth muscle cells. J Cell Physiol 2006, 207.757-766.

38. Hanafusa N, Yatomi Y, Yamada K, Hori Y, Nangaku M, Okuda T, Fujita T, Fukagawa M: Sphingosine 1-phosphate stimulates rat mesangial cell proliferation from outside the cells. Nephrol Dial Transplant 2002, 17:580-586

39. Chae SS, Paik JH, Furneaux H, Hla T: Requirement for sphingosine 1phosphate receptor-1 in tumor angiogenesis demonstrated by in vivo RNA interference. J Clin Invest 2004, 114:1082-1089.

doi: 10.1186/1471-2121-11-45

Cite this article as: Blom et al., An autocrine sphingosine-1-phosphate signaling loop enhances NF-?B-activation and survival BMC Cell Biology 2010 $11: 45$ 